\title{
PREPARATION AND INVESTIGATION OF GEOPOLYMERS GENERATED FROM CONSTRUCTION, DEMOLITION AND INDUSTRIAL WASTES
}

\author{
BELLA UDVARDI, KRISZTINA ROMÁN, EMESE KUROVICS, RÓBERT GÉBER \& ISTVÁN KOCSERHA \\ Institute of Ceramics and Polymer Engineering, University of Miskolc, Hungary
}

\begin{abstract}
Geopolymers are inorganic amorphous aluminosilicate materials, which can be produced by the alkali activation of materials with high aluminum and silicon content. In this research, we prepared geopolymer samples obtained from construction and demolition $(C \& D)$ waste materials (brick powder and concrete powder), as well as industrial waste material (aluminum dross), and we investigated them using different test methods. Density, particle size distribution and chemical elemental composition were determined on the dried powdered waste materials, and microstructural observations were also made using a scanning electron microscope (SEM) technique. To prepare the geopolymer sample mixtures of sodium-hydroxide and sodium silicate, we used an alkali activator solution at different concentrations (4 M, $8 \mathrm{M}$ and $12 \mathrm{M}$ ). We used Fourier Transformation Infrared Spectroscopy (FTIR) to reveal new phases in geopolymer samples. Compression strength was determined after 7 days and after 28 days. In the cases when aluminum dross was used, a gas-forming reaction took place in the geopolymer pastes; therefore, foamed geopolymer was produced. According to these results, the used $\mathrm{C} \& \mathrm{D}$ and industrial wastes may be potential raw materials which could be used to prepare geopolymers. Keywords: carbon dioxide, geopolymers, foamed geopolymer, construction waste, demolition waste, aluminum dross, compression strength, material microscopy.
\end{abstract}

\section{INTRODUCTION}

Geopolymers are amorphous materials with an inorganic polymer structure. They can be prepared in an alkaline medium (generally sodium hydroxide $(\mathrm{NaOH})$ or potassium hydroxide $(\mathrm{KOH})$ ), by the reaction of clay minerals (aluminosilicate oxides) and alkali silicates. They have a polysyalate structure; therefore, geopolymers are so-called artificially produced rocks. Geopolymers are today's modern and environmentally friendly binder material for the construction and building industry, which can compete with traditional concretes. During the production of ordinary Portland cement (OPC) a large amount of carbon-dioxide $\left(\mathrm{CO}_{2}\right)$ at $\sim 0.5-0.95$ tons/ 1 ton are emitted into the atmosphere, promoting global warming [1], [2]. In contrast, the production of geopolymers produces significantly less $\mathrm{CO}_{2}(\sim 10-20 \%$ of the OPC emissions) [3], [4]. Some properties of these materials are: resistance against acids, heat and fire; good mechanical strength; and the ability to encapsulate toxic materials.

For the synthesis of geopolymers, metakaolin and silicate-containing sources and industrial wastes can be used as the raw materials, such as: power plant waste (e.g. fly ash), metallurgical slag (e.g. ground granular blast furnace slag), waste incineration by-products (e.g. incinerator bottom ash), red mud, waste glass, or construction and demolition (C\&D) waste materials. Researchers are continuously looking for other possible materials which can be used for geopolymer production. The following section summarizes the actual trends and research results.

In the work of Nazari and Sanjayan [5], the synthesis possibility of geopolymeric paste and concrete through alkali activation of aluminum and grey cast iron slags were studied. Mixtures of slags were used as the aluminosilicate source; while waterglass, sodium 
hydroxide, polycarboxylate superplasticizer and natural sand were used to prepare geopolymer samples.

Compressive strength and workability were studied. The results indicated the possibility of geopolymers being produced by use of proper ratios of aluminum slag and grey cast iron slag. Islam et al. [6] prepared lightweight geopolymer mortar using palm oil fuel ash (POFA), ground granulated blast furnace slag (GGBFS) and low calcium fly-ash (FA) with manufactured sand (M-sand). During their research, compressive strength and density changes were studied. The authors found that the compressive strength of geopolymer samples increase up to $70 \%$ with the increase of ground granulated blast furnace slag. The highest compressive strength $(60 \mathrm{MPa})$ was achieved with the mixture of $30 \%$ palm oil fuel ash and 70\% ground granulated blast furnace slag. Puligilla and Mondal [7] used Class F fly ash and GGBFS to produce geopolymer. In their research, the hardening rate was tested and microstructural changes were observed. They found that calcium strongly affects the early and late age properties of a hardened geopolymer. They also concluded that calcium enhances geopolymer gel formation. Nath and Kumar [8] prepared geopolymer samples with the use of GGBFS and granulated corex slag (GCS) with Class F fly ash. Compressive strength, isothermal conduction calorimetry, Fourier transformation infrared spectroscopy and microstructural observation were done on these samples. They studied the effect of slag addition on the reaction kinetics. The authors found that compressive strength is increased with an increase in slag amounts. They also concluded that GCS can be a potential substitute material for GGBFS. Other researchers [9]-[12] also dealt with the utilization of different slags (primary lead slag, zync slag, alkaline activated ground blast furnace slag, lead smelting slag) in order to prepare geopolymers.

Tuyan et al. [13] produced waste clay brick powder-based geopolymer composites and the effect of the alkali solution concentration on the curing conditions and compressive strength were investigated. The morphology and structure of the composites were characterized by use of X-ray powder diffraction (XRD) analysis, thermogravimetric (TG) analysis, Fourier transform infrared spectroscopy (FTIR) analysis and scanning electron microscopy (SEM). The results of their examination show that the maximum compression strength was $36.2 \mathrm{MPa}$, which was achieved at $90^{\circ} \mathrm{C}, 40 \%$ relative humidity and 5 days of curing. Muhammad et al. [14] made a review that was about the suitability of clay application as a geopolymer material in brick production. According to their findings in the literature, it had been established that clay has high $\mathrm{SiO}_{2}$ and $\mathrm{Al}_{2} \mathrm{O}_{3}$ content; therefore, clay-based geopolymer has a good potential for geopolymer brick production. Brînduş-Simuţ et al. [15] investigated the effect of particle size of the waste brick powder on the properties of geopolymers. Five different fractions of waste bricks were used in their research, and the effect of this particle size on the rheological properties (yield stress and viscosity) were then revealed. The flexural and compressive strength of the hardened products were determined after 7, 14 and 90 days. The microstructure and pore structure of the geopolymer samples was examined by porosimetry and by SEM. The authors found that the flexural strength of geopolymer samples increased at $20^{\circ} \mathrm{C}$ with the increase of the particle size of waste brick powder. Compressive strength, depending on the particle size, was continuously increased until 28 days. Ren and Zhang [16] made a complete investigation in the field of recycling and utilization of waste concrete (with coarse and fines particles) for making new geopolymer concrete products. Compressive strength and initial setting time were determined. According to the results, the authors found that waste concrete is suitable for recycling and to produce new geopolymer.

In order to prepare geopolymers that are even more environmentally friendly, it is preferable to use industrial by-products and waste materials as the solid raw materials. The 
amount of environmental pollutants is growing rapidly, and these materials are mainly deposited in landfills, but it is not a definitive solution. This problem may be solved by the utilization of these wastes in geopolymers. The most frequently used secondary materials for geopolymer production are fly ash and slags [17]-[21].

As the above research results also confirm, utilization of different waste materials is economically and environmentally important. Therefore, the aim of this research is to prepare geopolymeric materials for different applications, using waste materials from different sources (C\&D wastes: brick and concrete powder; and industrial waste: aluminum dross).

\section{MATERIALS AND METHODS}

\subsection{Sample preparation}

During this research, the following materials were used to prepare geopolymer samples: aluminum dross (D), brick powder (B), concrete powder (C) and sand (S), as well as alkali activator $\left(\mathrm{NaOH}\right.$ solution) with waterglass $\left(\mathrm{Na}_{2} \mathrm{SiO}_{3}\right)$ and water. Also aluminum dross, a byproduct of the aluminum casting process. $B$ and $C$ are originated from $C \& D$ wastes. In addition, high purity natural sand was also used. $\mathrm{A} \mathrm{NaOH}$ solution was prepared from $\mathrm{NaOH}$ flakes and distilled water, in order to achieve different concentrations (4 M, $8 \mathrm{M}$ and $12 \mathrm{M}$ ).

The required particle size of powders was produced by means of a hammer, then by planetary ball mill. Samples were then dried to a weight constancy and closed air-proof for further examination. Fig. 1 illustrates the raw materials used for sample preparation. The geopolymer samples were prepared by the following procedure, according to Karyawan et al. [22] (Fig. 2).

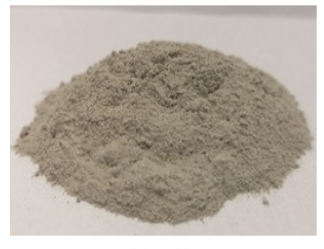

Sand

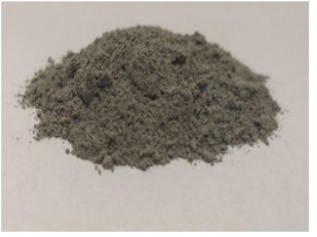

Aluminum dross

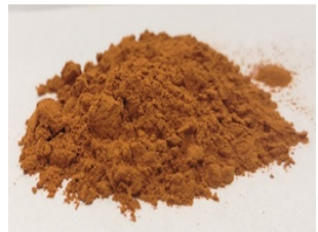

Brick powder

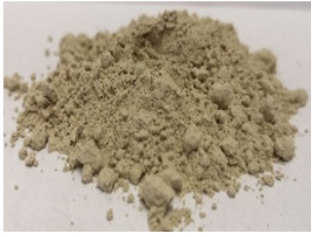

Concrete powder

Figure 1: Materials used for geopolymer preparation.

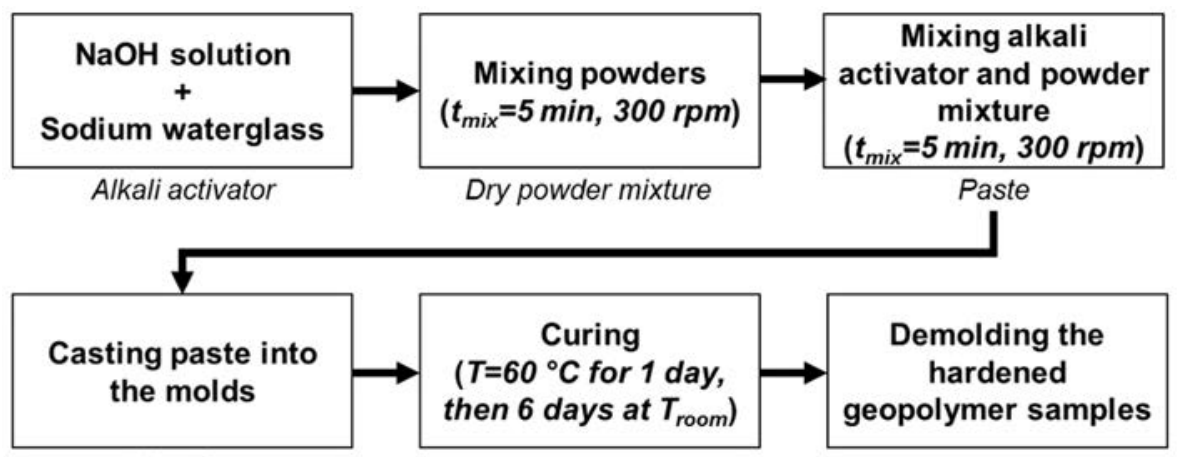

Forming

Figure 2: Sample preparation steps for geopolymer samples. 
Geopolymer samples were produced using different proportions of powdered waste materials and different concentrations of alkali activator solution according to Table 1 . Samples were prepared also standalone and in mixtures. A total of 24 mixtures were made. After mixing the powder and liquid components, geopolymer pastes were cast into the molds. The samples were then put in a sealed container and were cured at $60^{\circ} \mathrm{C}$ for 24 hours, in a confined space.

Table 1: Composition of geopolymer samples made with $4 \mathrm{M}, 8 \mathrm{M}$ and $12 \mathrm{M} \mathrm{NaOH}$.

\begin{tabular}{|c|c|c|c|c|c|c|c|c|}
\hline \multirow{2}{*}{$\begin{array}{c}\text { Sample } \\
\text { ID }\end{array}$} & \multirow{2}{*}{$\begin{array}{l}\text { Concentration } \\
\text { of } \mathrm{NaOH}(\mathrm{M})\end{array}$} & \multicolumn{2}{|c|}{$\begin{array}{c}\text { Alkali activator } \\
(\mathrm{m} / \mathrm{m} \%)\end{array}$} & \multirow{2}{*}{$\begin{array}{l}\text { Water } \\
(\mathrm{m} / \mathrm{m} \%)\end{array}$} & \multirow{2}{*}{$\begin{array}{l}\text { Sand } \\
(\mathrm{m} / \mathrm{m} \%)\end{array}$} & \multirow{2}{*}{$\begin{array}{c}\text { Aluminum } \\
\text { dross } \\
(\mathrm{m} / \mathrm{m} \%)\end{array}$} & \multirow{2}{*}{$\begin{array}{c}\text { Brick } \\
\text { powder } \\
(\mathrm{m} / \mathrm{m} \%)\end{array}$} & \multirow{2}{*}{$\begin{array}{c}\text { Concrete } \\
\text { powder } \\
(\mathrm{m} / \mathrm{m} \%)\end{array}$} \\
\hline & & $\mathrm{NaOH}$ & $\mathrm{Na}_{2} \mathrm{SiO}_{3}$ & & & & & \\
\hline D & \multirow{6}{*}{4} & 10 & 20 & 0 & 0 & 70 & 0 & 0 \\
\hline B & & 10 & 20 & 10 & & 0 & 60 & 0 \\
\hline $\mathrm{C}$ & & 10 & 20 & 0 & 0 & 0 & 0 & 70 \\
\hline DB & & 10 & 20 & 10 & 0 & 30 & 30 & 0 \\
\hline DSB & & 10 & 20 & 0 & 8.33 & 30.83 & 30.83 & 0 \\
\hline DSBC & & 10 & 20 & 0 & 8.33 & 41.66 & 10 & 10 \\
\hline D & \multirow{6}{*}{8} & 10 & 20 & 0 & 0 & 70 & 0 & 0 \\
\hline B & & 10 & 20 & 0 & 0 & 0 & 70 & 0 \\
\hline $\mathrm{C}$ & & 10 & 20 & 0 & 0 & 0 & 0 & 70 \\
\hline DB & & 10 & 20 & 10 & 0 & 35 & 35 & 0 \\
\hline DSB & & 10 & 20 & 0 & 8.33 & 30.83 & 30.83 & 0 \\
\hline DSBC & & 10 & 20 & 0 & 8.33 & 41.66 & 10 & 10 \\
\hline $\mathrm{D}$ & \multirow{6}{*}{12} & 10 & 20 & 0 & 0 & 70 & 0 & 0 \\
\hline B & & 10 & 20 & 10 & 0 & 0 & 60 & 0 \\
\hline $\mathrm{C}$ & & 10 & 20 & 0 & 0 & 0 & 0 & 70 \\
\hline DB & & 10 & 20 & 0 & 0 & 35 & 35 & 0 \\
\hline DSB & & 10 & 20 & 0 & 8.33 & 30.83 & 30.83 & 0 \\
\hline DSBC & & 10 & 20 & 0 & 8.33 & 41.66 & 10 & 10 \\
\hline
\end{tabular}

\subsection{Experimental methods}

For the morphological tests, a Carl Zeiss EVO MA10 scanning electron microscope (SEM) was used. Further observation was done by taking high resolution electron micrographs. Chemical elemental analysis (Energy Dispersive X-Ray Spectroscope (EDX)) was also made on the powders, during microstructural examination. We determined chemical composition by X-ray fluorescence spectrometry (XRF) on a Rigaku Super Mini 200 tabletop wavelength dispersive spectrometer.

The particle size distribution (PSD) of the ground materials was measured by a Malvern Mastersizer X particle size analyzer. To study the effect of geopolymerization on the 
geopolymers and to reveal chemical bonds, we used the Fourier transformation infrared spectroscopy method (FTIR) with a Bruker Tensor 27 instrument. Compressive strength of the hardened geopolymer samples was determined by the Instron 5566 Universal Material Tester instrument. We also determined the density of our geopolymer samples.

\section{RESULTS AND DISCUSSION}

The chemical element composition of powders as determined by EDX are summarized in Table 2.

Table 2: Chemical element composition of raw materials.

\begin{tabular}{|c|c|c|c|c|}
\hline $\begin{array}{c}\text { Chemical } \\
\text { element }\end{array}$ & $\begin{array}{c}\text { Sand } \\
(\mathrm{wt} \%)\end{array}$ & $\begin{array}{c}\text { Aluminum dross } \\
(\mathrm{wt} \%)\end{array}$ & $\begin{array}{c}\text { Brick powder } \\
(\mathrm{wt} \%)\end{array}$ & $\begin{array}{c}\text { Concrete powder } \\
(\mathrm{wt} \%)\end{array}$ \\
\hline $\mathrm{C}$ & 34.13 & 24.32 & 25.94 & 15.76 \\
\hline $\mathrm{O}$ & 35.39 & 20.58 & 34.94 & 37.40 \\
\hline $\mathrm{Na}$ & 0.09 & 7.60 & 0.35 & 0.48 \\
\hline $\mathrm{Mg}$ & 0.25 & 2.32 & 0.75 & 0.95 \\
\hline $\mathrm{Al}$ & 1.33 & 22.47 & 8.92 & 2.39 \\
\hline $\mathrm{Si}$ & 25.68 & 0.79 & 21.30 & 23.73 \\
\hline $\mathrm{S}$ & 0 & 0 & 0 & 0.65 \\
\hline $\mathrm{K}$ & 0.65 & 4.02 & 1.67 & 0.98 \\
\hline $\mathrm{Ca}$ & 2.34 & 1.82 & 0.53 & 15.90 \\
\hline $\mathrm{Fe}$ & 0 & 0 & 5.31 & 0 \\
\hline $\mathrm{Cl}$ & 0.13 & 16.08 & 0 & 0 \\
\hline $\mathrm{Ti}$ & 0 & 0 & 0.29 & 99.98 \\
\hline $\mathrm{TOTAL}$ & 99.99 & 100 & 100 & 1.74 \\
\hline
\end{tabular}

Note: Al: Aluminum; C: carbon; Ca: calcium; Cl: chloride; Fe: iron; K: potassium; Mg: magnesium; Na: sodium; O: oxygen; S: sulfur; Si: silica; Ti: titanium.

Our results show that sand contains a high amount of $\mathrm{Si}$, which indicates the presence of $\mathrm{SiO}_{2}$. Besides, a low amount of $\mathrm{Al}$ was also detected, which refers to the presence of alumina $\left(\mathrm{Al}_{2} \mathrm{O}_{3}\right)$. A significant amount of $\mathrm{Al}, \mathrm{Na}, \mathrm{K}$ and $\mathrm{Cl}$ were detected in aluminum dross. These elements indicate the presence of alumina and the slag-forming agents $\mathrm{NaCl}$ and $\mathrm{KCl}$. Brick powder contains a high amount of $\mathrm{Si}$ and a significant amount of $\mathrm{Fe}$ and $\mathrm{Al}$. Si refers to $\mathrm{SiO}_{2}$, while having $\mathrm{Al}$ and $\mathrm{Fe}$ shows the presence of alumina and $\mathrm{Fe}_{2} \mathrm{O}_{3}$. High amount of $\mathrm{Si}$ and $\mathrm{Ca}$ were detected in concrete powder. This suggests the presence of $\mathrm{SiO}_{2}$ and $\mathrm{CaO}$, which are the main oxides of cement minerals.

During our research work, scanning electron micrographs were taken to observe the microstructure and the surface features of powders. Fig. 3 shows that sand and Al dross contain coarser particles than brick and concrete powders; however, these powders contain high amount of fine particles, as well. Smaller particles were stuck on the surface of bigger grains. In the case of aluminum dross, the brick powder and concrete powder there are particles that are glued together.

Table 3 shows the chemical composition of powders, as determined by XRF. The XRF results show that sand contains a high amount of $\mathrm{SiO}_{2}$. The loss of ignition (LOI) is due to the evaporation of absorbed water. The LOI values of brick powder and concrete powder are linked to the amorphous materials. Opposite to this, the LOI of aluminum dross is significantly higher. The reason for this is the evaporation of slag-forming agents. 


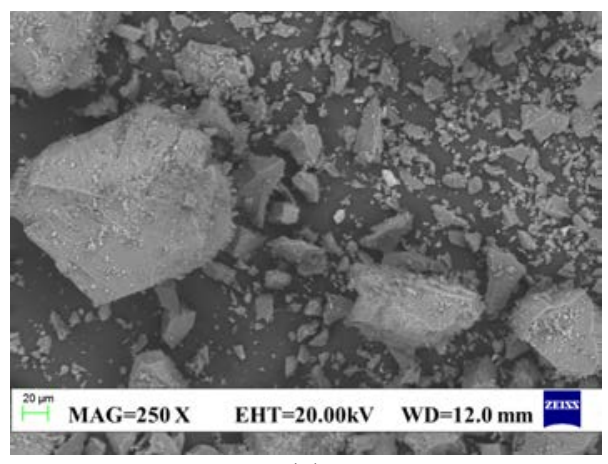

(a)

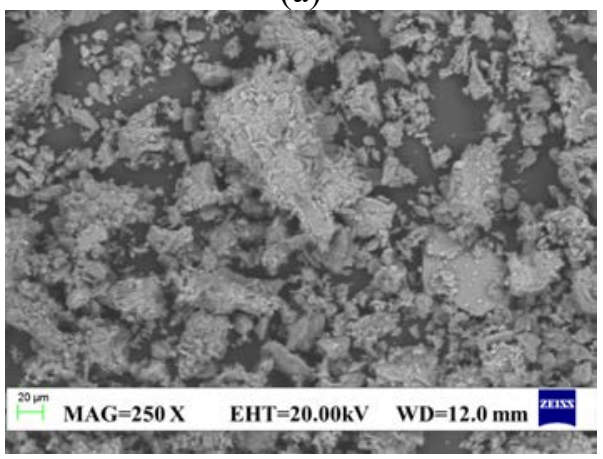

(c)

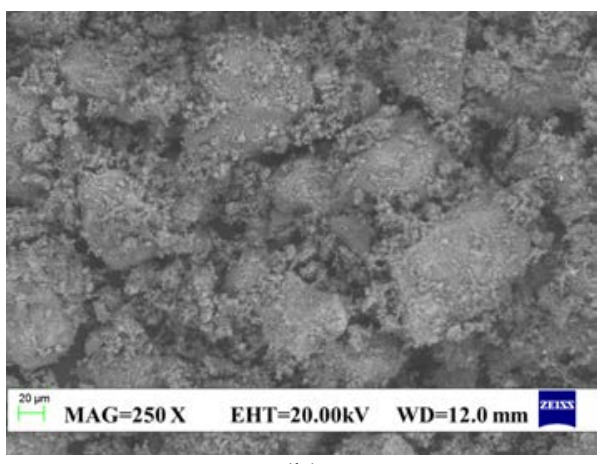

(b)

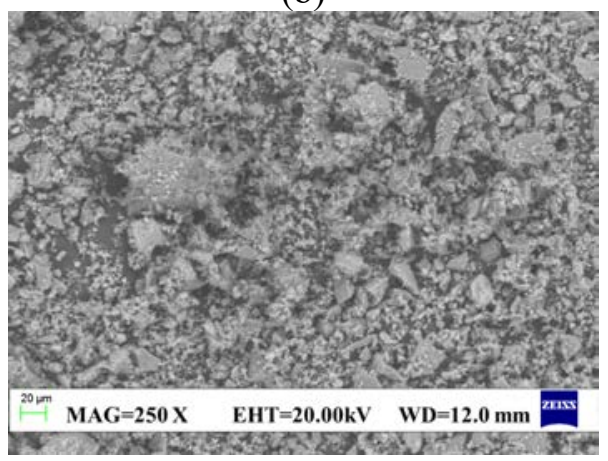

(d)

Figure 3: SEM micrographs of powders. (a) Sand; (b) Aluminum dross; (c) Brick powder; and (d) Concrete powder.

Table 3: Chemical composition of powders.

\begin{tabular}{|c|c|c|c|c|}
\hline Compounds & $\begin{array}{c}\text { Sand } \\
(\mathrm{wt} \%)\end{array}$ & $\begin{array}{c}\text { Aluminum dross } \\
(\mathrm{wt} \%)\end{array}$ & $\begin{array}{c}\text { Brick powder } \\
(\mathrm{wt} \%)\end{array}$ & $\begin{array}{c}\text { Concrete powder } \\
(\mathrm{wt} \%)\end{array}$ \\
\hline $\mathrm{SiO}_{2}$ & 83.55 & 18.14 & 60.97 & 67.4 \\
\hline $\mathrm{Al}_{2} \mathrm{O}_{3}$ & 2.46 & 35.93 & 19.49 & 4.2 \\
\hline $\mathrm{MgO}$ & 0.26 & 3.81 & 1.65 & 1.73 \\
\hline $\mathrm{CaO}$ & 2.33 & 1.91 & 0.72 & 14.6 \\
\hline $\mathrm{Na}_{2} \mathrm{O}$ & 0.09 & 10.57 & 0.79 & 0.46 \\
\hline $\mathrm{K}_{2} \mathrm{O}$ & 0.52 & 3.36 & 2.26 & 0.84 \\
\hline $\mathrm{Fe}_{2} \mathrm{O}_{3}$ & 1.48 & 0.32 & 7.03 & 1.14 \\
\hline $\mathrm{MnO}^{\mathrm{TiO}}{ }_{2}$ & 0.046 & 0.104 & 0.105 & 0.147 \\
\hline $\mathrm{P}_{2} \mathrm{O}_{5}$ & 3.340 & 0.207 & 1.230 & 0.155 \\
\hline $\mathrm{TOTAL}_{\mathrm{O}}$ & 9.014 & 0.050 & 0.090 & 0.062 \\
\hline $\mathrm{LOI}$ & 5,91 & 74.40 & 94.34 & 90.73 \\
\hline
\end{tabular}



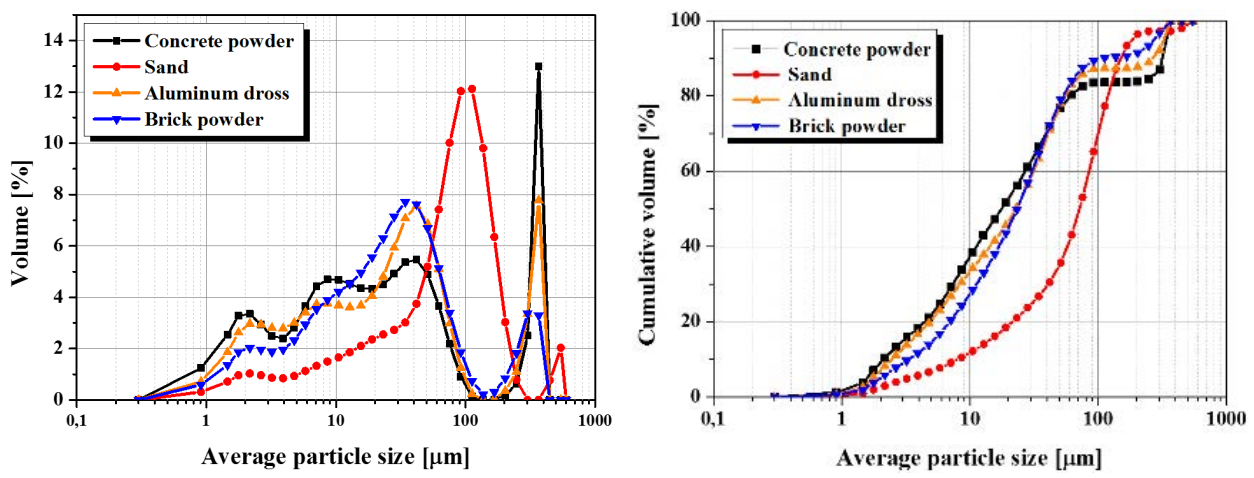

Figure 4: Particle size distribution of powder materials.

Fig. 4 shows the results of volume distribution and cumulative volume.

It can be concluded that all of the powders are polydispersed materials. Concrete powder has four modes, three of these are below $100 \mu \mathrm{m}$. This powder has a narrow peak of around $350 \mu \mathrm{m}$. Aluminum dross has a similar distribution, while brick powder has a significant volume, around 40 microns. Sand has a low volume in fine particles, while it has a wide peak that can be seen around 100 microns. Average particle sizes $\left(\mathrm{d}_{50}\right)$ are the following: $\mathrm{d}_{50 \mathrm{C}}$ : $20 \mu \mathrm{m}<\mathrm{d}_{50 \mathrm{D}}: 26 \mu \mathrm{m}<\mathrm{d}_{50 \mathrm{~B}}: 26 \mu \mathrm{m}<\mathrm{d}_{50 \mathrm{~s}}: 79 \mu \mathrm{m}$. Concrete powder, aluminum dross and brick powder have a significant volume of fine particles below 10 microns.

Particle density of the powders studied were determined by the pycnometer method, according to standard (EN 1097-7) [23]. Our results show that concrete powder has the lowest density $\left(\rho_{\mathrm{C}}=1.24 \mathrm{~g} / \mathrm{cm}^{3}\right)$; while the other three materials have the following particle density: $\rho_{\mathrm{D}}=2.90 \mathrm{~g} / \mathrm{cm}^{3}, \rho_{\mathrm{B}}=2.78 \mathrm{~g} / \mathrm{cm}^{3}$ and $\rho_{\mathrm{S}}=2.62 \mathrm{~g} / \mathrm{cm}^{3}$.

Fig. 5 shows a summarized example of the FTIR spectras from Table 4, which contains all the characteristic compounds or ions of geopolymer samples, as well.

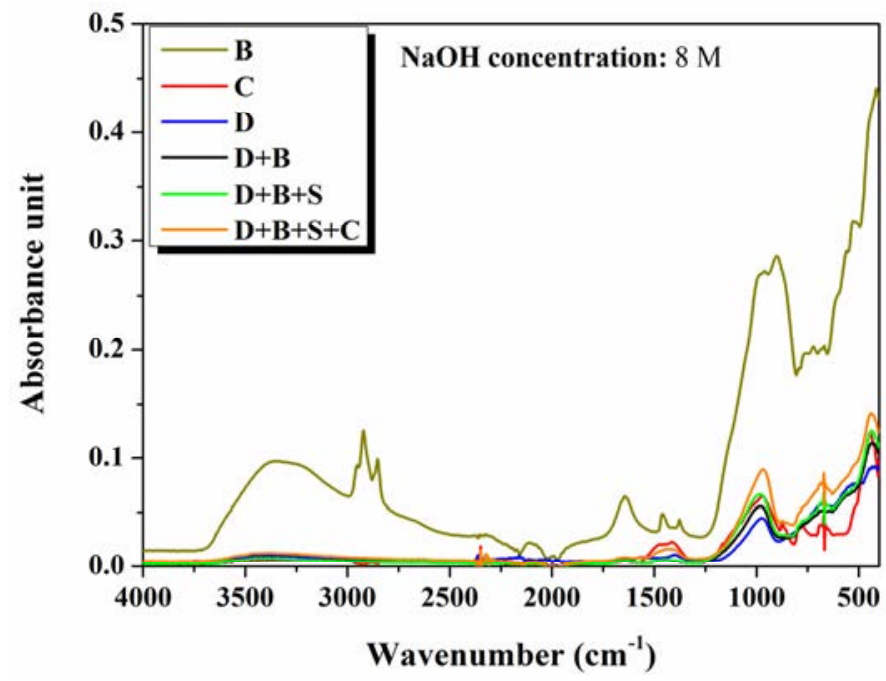

Figure 5: FTIR results of geopolymer samples ( $\mathrm{NaOH}$ concentration: $8 \mathrm{M})$. 
Table 4: Compounds' characteristic absorption.

\begin{tabular}{|c|c|c|}
\hline $\begin{array}{l}\text { Concentration of } \mathrm{NaOH} \\
(\mathrm{M})\end{array}$ & $\begin{array}{l}\text { Characteristic compounds or } \\
\text { ion }\end{array}$ & $\begin{array}{c}\text { Wavenumber } \\
\left(\mathrm{cm}^{-1}\right)\end{array}$ \\
\hline \multirow{10}{*}{ 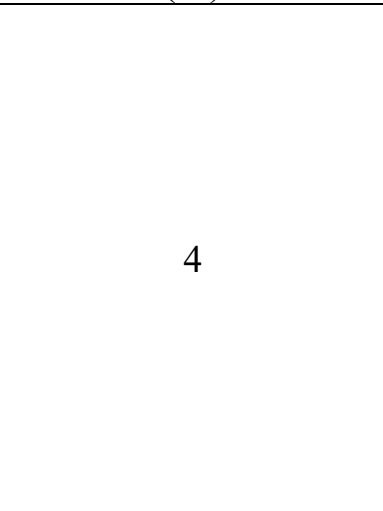 } & $\mathrm{OH}^{-}$ & 3368.79 \\
\hline & $\mathrm{OH}^{-}$ & 3238.18 \\
\hline & organic compound & 2922.79 \\
\hline & $\mathrm{NH}_{3}$ & 2325.40 \\
\hline & $\mathrm{Ca}_{2} \mathrm{MgSi}_{2} \mathrm{O}_{7}$ & 1643.13 \\
\hline & $\mathrm{MgO}$ & 1385.94 \\
\hline & Si-O-Si & $1004.09-1001.20$ \\
\hline & $\mathrm{MgCO}_{3}$ & 775.88 \\
\hline & $\mathrm{Si}_{2} \mathrm{O}_{3}{ }^{2-}$ & 692.63 \\
\hline & $\mathrm{SiO}_{2}$ & $442.64-439.29$ \\
\hline \multirow{12}{*}{8} & $\mathrm{OH}^{-}$ & 3333.20 \\
\hline & organic compound $\left(\mathrm{CH}_{8}\right)$ & 2922.02 \\
\hline & organic compound $\left(\mathrm{CH}_{2}\right)$ & 2852.93 \\
\hline & $\mathrm{NH}_{3}$ & $2349.33-2322.86$ \\
\hline & $\mathrm{Ca}_{2} \mathrm{MgSi}_{2} \mathrm{O}_{7}$ & 1643.55 \\
\hline & $\mathrm{CO}_{3}^{2-}$ & $1461.21-1376.98$ \\
\hline & $\mathrm{Si}-\mathrm{O}$ & $990.02-906.87$ \\
\hline & $\mathrm{MgCO}_{3}$ & $795.13-770.22$ \\
\hline & $\mathrm{O}-\mathrm{Si}-\mathrm{O}$ & $671.25-664.55$ \\
\hline & $\mathrm{Ca}=\mathrm{O}$ & 615.15 \\
\hline & $\mathrm{MgO}$ & $563.51-532.81$ \\
\hline & $\mathrm{SiO}_{2}$ & $451.65-445.54$ \\
\hline \multirow{13}{*}{12} & $\mathrm{OH}^{-}$ & 3200.80 \\
\hline & organic compound $\left(\mathrm{CH}_{8}\right)$ & 2921.90 \\
\hline & organic compound $\left(\mathrm{CH}_{2}\right)$ & 2852.52 \\
\hline & $\mathrm{Ca}_{2} \mathrm{MgSi}_{2} \mathrm{O}_{7}$ & 1683.82 \\
\hline & Crystal water & 1662.19 \\
\hline & $\mathrm{MgCO}_{3}$ & 1653.44 \\
\hline & $\mathrm{Ca}_{2} \mathrm{MgSi}_{2} \mathrm{O}_{7}$ & 1646.22 \\
\hline & $\mathrm{NH}_{3}$ & 1635.95 \\
\hline & $\mathrm{CO}_{3}^{2-}$ & 1457.17 \\
\hline & $\mathrm{MgO}$ & 1375.92 \\
\hline & Si-O & 989.02 \\
\hline & $\mathrm{MgCO}_{3}$ & 774.05 \\
\hline & $\mathrm{SiO}_{2}$ & 444.00 \\
\hline
\end{tabular}


Typical bands of multi-atom inorganic ions are generally much more intense and wider than those of organic compounds. The frequency of the vibrations corresponding to the different bonds depends on the strength of the bond and the weight of the atoms involved in the bond. The most intense changes in material structure were observed in the case of $12 \mathrm{M}$ $\mathrm{NaOH}$ concentration.

Table 5 contains the results of compression strength values and density values of the geopolymer samples, depending on the age and concentration of $\mathrm{NaOH}$ used to make them. Note that in some cases, samples were broken during demolding; therefore, the determination of strength and density were not possible.

Table 5: Density of geopolymer samples.

\begin{tabular}{|c|c|c|c|c|}
\hline \multirow{2}{*}{ Sample ID } & \multirow{2}{*}{$\begin{array}{c}\text { Concentration of } \\
\text { NaOH }(\mathrm{M})\end{array}$} & \multicolumn{2}{|c|}{$\begin{array}{c}\text { Compression strength } \\
(\mathrm{MPa})\end{array}$} & \multirow{2}{*}{$\begin{array}{c}\text { Density of sample } \\
\left(\mathrm{g} / \mathrm{cm}^{3}\right)\end{array}$} \\
\cline { 3 - 4 } & & 7 days & 28 days & - \\
\hline B & 4 & - & - & 1.16 \\
\hline D & 4 & 0.62 & 0.82 & 1.42 \\
\hline C & 4 & 3.19 & 4.69 & - \\
\hline DB & 4 & - & - & 1.38 \\
\hline DSB & 4 & 0.58 & 0.50 & 1,51 \\
\hline DSBC & 4 & 1.36 & 1.52 & 1.76 \\
\hline B & 8 & 4.27 & 9.85 & 0.93 \\
\hline D & 8 & 1.77 & 1.86 & 1.96 \\
\hline C & 8 & 3.38 & 17.13 & 0.89 \\
\hline DB & 8 & 0.07 & 0.87 & 0.91 \\
\hline DSB & 8 & 0.54 & 1.07 & 0.87 \\
\hline DSBC & 8 & 0.90 & 0.87 & - \\
\hline B & 12 & - & - & 1.06 \\
\hline D & 12 & 1.92 & 1.81 & 1.43 \\
\hline C & 12 & 9.04 & 11.72 & - \\
\hline DB & 12 & - & - & 0.99 \\
\hline DSB & 12 & 0.73 & 0.97 & 1.02 \\
\hline DSBC & 12 & 0.89 & 1.15 & \\
\hline & & & & \\
\hline
\end{tabular}

The results show the compression strengths and density values of the geopolymer samples tested. Note that density values of these geopolymers were determined according to the dimensions of sample particles. It can be concluded that using only brick powder or the mixture of brick powder and aluminum dross geopolymers could not be formed, in the case of both $4 \mathrm{M}$ and $12 \mathrm{M} \mathrm{NaOH}$ concentration. Only $8 \mathrm{M} \mathrm{NaOH}$ was appropriate to form a geopolymer structure.

Using aluminum dross, geopolymer pastes were foamed according to the reaction of the metallic aluminum and water. During this reaction hydrogen gas was formed, resulting in a foaming process. Consequently, geopolymers containing aluminum dross have a lower density and low mechanical strength. Geopolymer structures were formed in all concentrations, when concrete powder was used. The highest compressive strength $(17.13 \mathrm{MPa})$ was achieved with $8 \mathrm{M} \mathrm{NaOH}$ concentration and the use of only concrete powder. 


\section{CONCLUSIONS}

In this research, the possibility of utilization of different $C \& D$ and industrial wastes was studied for their ability to prepare useful geopolymer materials. Complex analyses were made on these powdered materials, and then their geopolymer samples were made using alkali activators. The most important properties, compressive strength and density, were determined. It can be concluded that not only the type and amount of waste materials affect the forming of a geopolymer structure, but the concentration of alkali activator is important. According to our results, concrete powder showed the highest compressive strength after 28 days; therefore, these wastes may be a potential raw material for making geopolymers. Brick powder may also be suitable as a raw material; however, in this case the use of a proper concentration of alkali activator is required. Using aluminum dross, a low density foamed geopolymer was prepared, which may be useful for thermal insulating.

\section{ACKNOWLEDGEMENTS}

The described article was carried out as part of the "Sustainable Raw Material Management Thematic Network - RING 2017" EFOP-3.6.2-16-2017-00010 project, performed within the framework of the Széchenyi2020 Program. The realization of this project is supported by the European Union, and was co-financed by the European Social Fund.

\section{REFERENCES}

[1] Onutai, S., Development of geopolymer materials sourced with fly ash and industrial waste. PhD thesis, 2016.

[2] Worrell, E., Price, L., Martin, N., Hendriks, C. \& Ozawa Meida, L., Carbon dioxide emissions from the global cement industry. Annual Review of Environment and Resources, 26, pp. 303-329, 2001. DOI: 10.1146/annurev.energy.26.1.303.

[3] Davidovits, J., Geopolymer Chemistry and Application, Institut Geopolimére: France, pp. 283-286, 2011.

[4] Mucsi, G., Lakatos, J., Molnár, Z. \& Szabó, R., Development of geopolymer using industrial waste materials. The 9th International Conference on Environmental Engineering, Vilnius Gediminas Technical University Press, 39, pp. 1-8, 2014.

DOI: 10.3846/enviro.2014.039.

[5] Nazari, A. \& Sanjayan, J.G., Synthesis of geopolymer from industrial wastes. Journal of Cleaner Production, 99, pp. 297-304, 2015. DOI: 10.1016/j.jclepro.2015.03.003.

[6] Islam, A., Alengaram, U.J., Jumaat, M.Z. \& Bashar, I.I., The development of compressive strength of ground granulated blast furnace slag-palm oil fuel ash-fly ash based geopolymer mortar. Materials and Design, 56, 833-841, 2014.

DOI: 10.1016/j.matdes.2013.11.080.

[7] Puligilla, S. \& Mondal, P., Role of slag in microstructural development and hardening of fly ash-slag geopolymer. Cement and Concrete Research, 43, pp. 70-80, 2013.

DOI: 10.1016/j.cemconres.2012.10.004.

[8] Nath, S.K. \& Kumar, S., Influence of iron making slags on strength and microstructure of fly ash geopolymer. Construction and Building Materials, 38, pp. 924-930, 2013. DOI: 10.1016/j.conbuildmat.2012.09.070.

[9] Onisei, S. et al., Synthesis of inorganic polymers using fly ash and primary lead slag. Journal of Hazardous Materials, 205, pp. 101-110, 2012.

DOI: 10.1016/j.jhazmat.2011.12.039.

[10] Alex, T.C. et al., Utilization of zinc slag through geopolymerization: Influence of milling atmosphere. International Journal of Mineral Processing, 123, pp. 102-107, 2013. DOI: 10.1016/j.minpro.2013.06.001. 
[11] Yusuf, M.O., Megat Johari, M.A., Ahmad, Z.A. \& Maslehuddin, M., Evolution of alkaline activated ground blast furnace slag-ultrafine palm oil fuel ash-based concrete. Materials and Design, 55, pp. 387-393, 2014. DOI: 10.1016/j.matdes.2013.09.047.

[12] Ogundiran, M.B., Nugteren, H.W. \& Witkamp, G.J., Immobilisation of lead smelting slag within spent aluminate-fly ash based geopolymers. Journal of Hazardous Materials, 248-249, pp. 29-36, 2012. DOI: 10.1016/j.jhazmat.2012.12.040.

[13] Tuyan, M., Andiç-Çakir, Ö. \& Ramyar, K., Effect of alkali activator concentration and curing condition on strength and microstructure of waste clay brick powder-based geopolymer. Composites Part B: Engineering, 135, pp. 242-252, 2018. DOI: 10.1016/j.compositesb.2017.10.013.

[14] Muhammad, F., Mustafa, A.B., Kamarudin, H., Binhussain, M., Ruzaidi, C.M. \& Izzat, A.M., Application of clay-based geopolymer in brick production: A review. Advanced Materials Research, 626, pp. 878-882, 2013.

DOI: 10.4028/www.scientific.net/AMR.626.878.

[15] Brînduş-Simuţ, J., Vyšvařil, M., Bayer, P., Keppert, M. \& Rovnaníková, P., Effect of particle size of waste brick powder on the properties of alkaline activated materials. International Conference Building Materials, Product and Technologies, 379, pp. 18, 2018. DOI: 10.1088/1757-899X/379/1/012019.

[16] Ren, X. \& Zhang, L., The complete recycling of waste concrete to produce geopolymer concrete. Civil Engineering and Engineering Mechanics, 272, pp. 103-111, 2016. DOI: 10.1061/9780784480151.011.

[17] Janosevic, N., Djoric-Veljkovic, S., Toplicic-Curcic, G. \& Karamarkovic, G., Properties of geopolymers. Architecture and Civil Engineering, 1(16), pp. 45-56, 2018. DOI: 10.2298/FUACE161226004J.

[18] Kumar, S. et al., Mechanical activation of fly ash and its influence on micro and nanostructural behaviour of resulting geopolymers. Advanced Powder Technology, 28, pp. 805-813, 2017. DOI: 10.1016/j.apt.2016.11.027.

[19] Daval, S. \& Soundarapandian, N., Effect of fly-ash based geopolymer coated aggregate on bituminous mixtures. Journal of the Croatian Association of Civil Engineers, 70, pp. 187-199, 2018. DOI: 10.14256/JCE.1678.2016.

[20] Dassekpo, J. et al., The effects of the sequential addition of synthesis parameters on the performance of alkali activated fly ash mortar. Results in Physics, 7, pp. 15061512, 2017. DOI: 10.1016/j.rinp.2017.04.019.

[21] Rafeet, A. et al., Guidelines for mix proportioning of fly ash/GGBS based alkali activated concretes. Construction and Building Materials, 147, pp. 130-142, 2017. DOI: 10.1016/j.conbuildmat.2017.04.036.

[22] Karyawan, I., Ahyudanari, E. \& Ekaputri, J., Potential use of fly ash base-geopolymer as aggregate substitution in asphalt concrete mixtures. International Journal of Engineering and Technology, 5(9), pp. 3744-3752, 2017.

DOI: $10.21817 / \mathrm{ijet} / 2017 / \mathrm{v} 9 \mathrm{i} / 170905005$.

[23] EN 1097-7, Tests for mechanical and physical properties of aggregates. Part 7: Determination of the particle density of filler. Pycnometer method, 2000. 